\title{
PENGGUNAAN MULTIPLEKS POL YMERASE CHAIN REACTION (PCR) DALAM MENDETEKSI JAMUR DERMATOFIT
}

\author{
The Use Multipleks Polymerase Chain Reaction (PCR) In Detection Of Dermatophytes \\ Aan Yulianingsih ${ }^{1}$, Rizalinda Sjahril ${ }^{2}$, Firdaus Hamid ${ }^{2}$ \\ 1 Jurusan Analis Kesehatan, Poltekkes Ternate \\ 2 Fakultas Kedokteran Universitas Hasanuddin \\ *) Email Korespondensi : aanyulianingsih@rocketmail.com
}

\begin{abstract}
Dermatophytes are fungi that belong to three genera: Epidermophyton, Trichophyton and Microsporum. This study aims to identify the causative dermatophytosis in patient using Multiplex PCR. This observational laboratory research was performed on 50 sample collected from several clinic and elementary schools in the city of Makassar. The results showed Microsporum spp. (54\%) dermatophyte was found. Thus we suggest that this laboratory tehnique is used to comfirm the etiology of patients with dermatohytosis.
\end{abstract}

Keywords : Dermatophytes, Fungi, Multipleks PCR

\section{ABSTRAK}

Dermatofitosis adalah salah satu jamur yang terdiri dari tiga genus: Epidermophyton, Trichophyton dan Microsporum. Tujuan penelitian ini untuk mengidentifikasi jenis jamur dermatofit dengan metode Multipleks PCR yang ditemukan pada penderita dermatofitosis di Kota Makassar. Penelitian observasi laboratorium dengan menguji 50 sampel yang diperoleh dari beberapa klinik dan sekolah dasar di Makassar. Hasil penelitian menunjukan bahwa Microsporum spp. terbanyak teridentifikasi (54\%). Kami menyarankan teknik Multipleks PCR ini digunakan untuk konfirmasi jenis dermatofit sehingga pengobatan dapat lebih cepat dan tepat.

Kata Kunci : Dermatofit, Jamur, Multipleks PCR 


\section{PENDAHULUAN}

Dermatofita adalah suatu kelompok taksonomi jamur yang menyerang kulit superfisial. Kemampuannya untuk membentuk ikatan molekuler terhadap keratin dan menggunakannya sebagai sumber makanan menyebabkan mereka mampu berkolonisasi pada jaringan keratin, termasuk juga pada stratum korneum epidermis di inguinal dan rambut pubis (Adiguna, 2011).

Dermatofit penyebab paling umum dari mikosis superfisial pada manusia dan hewan, yang mempengaruhi jutaan orang setiap tahun. Diperkirakan risiko seumur hidup yang tertular infeksi dermatofit adalah 10-20\% (Garg et al., 2009).

Pada tahun 2013, terdapat 153 kasus dermatofitosis yang berkunjung ke Poliklinik Kulit dan Kelamin RSUP Prof. Dr. R. D. Kandou Manado (Sondakh et al., 2016). Sedangkan di Makassar sendiri menurut penelitian yang dilakukan oleh Paramata \& Massi (2009) menunjukkan bahwa dari 60 sampel squama yang diperoleh terdapat 50 sampel yang menunjukkan dermatofita.

Klasifikasi dan identifikasi dermatofit yang dilakukan saat ini sesuai dengan manifestasi klinis, pemeriksaan gross koloni dari kultur, pemeriksaan mikroskopis dari makro dan mikro-konidia, karakteristik biokimia. Namun, identifikasi ini memakan waktu dan dapat menimbulkan kesulitan bagi yang bukan ahlinya dalam mengidentifikasi morfologi koloni, bahkan mungkin strain yang sama menunjukkan morfologi koloni yang beragam, membuat identifikasi organisme penyebabnya lebih sulit. (Kim et al., 2011).

Untuk menjawab kekurangan dan keterbatasan dari sistem identifikasi ini, maka sejumlah penelitian baru-baru ini dilaporkan untuk mengembangkan sistem yang lebih cepat dan lebih tepat dengan bantuan berbagai teknik biologi molekuler, salah satunya dengan menggunakan teknik Polymerase Chain Reaction (PCR) yang cukup berguna dan dapat dilakukan dengan cepat di laboratorium umum. Namun, antara spesies individu dermatophyta, perbedaan ITS1-2 (Internal Trancribed Spacer 1-2), 18S RNA (ribonucleic acid) ribosom, dan 28S RNA ribosom tidak signifikan sehingga membuat pengembangan primer spesies yang spesifik sangat sulit. Penggunaan metode sekuensing DNA (deoxyribonucleic acid) PCR dapat menghasilkan hasil yang sangat handal. Namun, aplikasi klinis sering terhambat oleh lamanya waktu yang dibutuhkan dan biaya (Lee, 2010).

Multipleks PCR dalam mengidentifikasi dermatofit dapat mengidentifikasi 11 spesies (Kim et al., 2011).

Berdasarkan hal tersebut diatas maka penelitian ini bertujuan untuk mengidentifikasi jenis jamur dermatofit yang ditemukan pada penderita dermatofitosis di Kota Makassar dengan metode Multipleks PCR.

\section{METODE \\ Desain, tempat dan waktu}

Penelitian dilakukan di Makassar dengan sampel diperoleh dari pasien di beberapa klinik dan Beberapa Sekolah Dasar di Makassar meliputi penetuan tipe klinik dermatofitosis dan pemeriksaan kerokan kulit $\mathrm{KOH} 10-20 \%$. Teknik PCR dilakukan di Laboratorium Mikrobiologi Rumah Sakit Pendidikan Universitas Hasanuddin dan dilakukan pada bulan Maret-Juli 2016. Jenis penelitian yang digunakan adalah metode observasional dilaboratorium.

\section{Bahan dan Alat}

Seperangkat alat PCR dan alat elektroforesis gel. Hasil kerokan jamur dari pasien dermatofitosis, $\mathrm{KOH} 10-20 \%$, primer PCR ( ITS 1 dan ITS 4, ITS 1-2, 18s RNA, 28s RNA), Malt ekstrak Agar, alcohol, Larutan $\mathrm{NaCl}$, natrium asetat, fenol, etanol $70 \%$, buffer TE, aquades, buffer TBE, zat warna etidium bromide, trifosfat deoxynucleoside (dATP, dCTP, dTTP), Taq Polymerase, DNA template, buffer TrisBorat EDTA, TBE, Bromphenol blue, Kappa master mix, nuclease free water.

\section{Langkah-langkah Penelitian}

1. Identifikasi dengan metode $\mathrm{KOH}$

Penderita yang secara klinis didiagnosis dermatofitosis dikerok pada bagian lesi kulit dengan menggunakan skapel kemudian ditampung di objek glass yang telah ditetesi $\mathrm{KOH} 10-20 \%$. Objek glass ditutup dengan deck glass dan dilihat di bawah mikroskop dengan pembesaran lensa objektif 10x untuk mengetahui adanya hifa dan spora

\section{Ekstraksi DNA}

sampel kerokan dimasukkan ke dalam tabung eppendorf, kemudian dilakukan ekstraksi DNA sesuai dengan petunjuk teknis yang terdapat pada kit ekstraksi DNA. 3. Multipleks PCR 
Primer yang digunakan yaitu ITS 1-2 (forward: ATCATTAACGCGGCAGGCreverse: TGGCCACTGCTTTTCGG), 18s RNA (forward: AAG TTG GGT CAA ACT CGGT- reverse: TGA TCC TTC CGC AGG TT) dan 28s RNA (forward: ACA GGG ATT GCC CCA GTA- Reverse: CTT GTT CGC TAT CGG CTC). Campuran reaksi

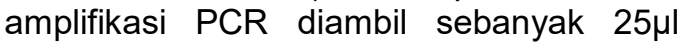
dengan enzim Kappa sebanyak 12,5 $\mu$, $\mathrm{MgCl}_{2} \quad 0,5 \mu \mathrm{l}$, primer forward $1 \mu \mathrm{l}$, primer reverse $1 \mu \mathrm{l}$ dan produk DNA $10 \mu \mathrm{l}$. Untuk ITS 1 dan 2, kondisi reaksi, sebagai berikut: 5 menit denaturasi pada suhu $94^{\circ} \mathrm{C}, 30$ detik annealing pada $60{ }^{\circ} \mathrm{C}$, dan satu menit ekstension pada $72{ }^{\circ} \mathrm{C}$. Seluruh proses diulang untuk 34 siklus, dengan ekstensi akhir pada $72{ }^{\circ} \mathrm{C}$ selama 10 menit. Kondisi PCR untuk 28S RNA adalah, sebagai berikut: 7 menit denaturasi pada $94^{\circ} \mathrm{C}, 30$ detik annealing pada $50{ }^{\circ} \mathrm{C}$, dan 1 menit ekstension pada $72{ }^{\circ} \mathrm{C}$. Seluruh proses diulang untuk 34 siklus, dengan ekstensi akhir pada $72{ }^{\circ} \mathrm{C}$ selama 10 menit. Kondisi PCR dari 18 S ribosom RNA sebagai berikut: 7 menit denaturasi pada $94{ }^{\circ} \mathrm{C}, 1$ menit annealing di $57,5^{\circ} \mathrm{C}$, dan 1 menit ekstension pada $72{ }^{\circ} \mathrm{C}$. Seluruh proses diulang untuk 34 siklus, dengan ekstensi akhir pada $72{ }^{\circ} \mathrm{C}$ selama 10 menit. DNA diamplifikasi diamati pada $2 \%(w / v)$ gel agarosa di TAE penyangga.

\section{Elektroforesis Gel agarosa}

Untuk mengetahui hasil amplifikasi DNA dilakukan proses elektroforesis terhadap produk PCR pada gel agarosa $2 \%$ dan perangkat elektroforesis dijalankan dengan mengalirkan aliran listrik 100 Volt () $400 \mathrm{~mA}$ selama 90 menit.

\section{Pengolahan dan analisis data}

Data yang diperoleh dikelompokkan berdasarkan tujuan dan jenis data kemudian di analisis dengan menggunakan tabel $2 \times 2$. Hasil analisis akan ditampilkan dalam bentuk tabel disertai penjelasan.

\section{HASIL}

Pengumpulan sampel dilakukan di Balai Kesehatan Kulit, Kelamin dan Kosmetik, Kartini medical center dan Beberapa Sekolah Dasar yang berada di Kota Makassar hingga jumlah sampel mencukupi 50. Teknik PCR dilakukan di Laboratorium Mikrobiologi Rumah Sakit Pendidikan Universitas Hasanuddin. Pada tabel 1 dilihat bahwa sebanyak 27 penderita (54\%) diderita oleh laki-laki sedangkan perempuan sebanyak 23 penderita (46\%). Dari segi umur sebanyak 23 penderita diderita oleh umur 0-18 tahun, sedangkan umur 19-45 tahun sebanyak 19 penderita dan umur $>45$ tahun sebanyak 8 penderita (Tabel 2). Hasil amplifikasi metode Multipleks PCR didapatkan hasil terbanyak yaitu Microsporum spp. yaitu 27 sampel kemudian dermatofit jenis lainnya (diluar 11 spesies) sebanyak 10 sampel lalu Trichophyton mentagrophytes var. interdigitale dan Microsporum audoinii masing-masing sebanyak 4 sampel, Microsporum vulvum sebanyak 3 sampel dan Trichophyton tonsurans dan Microsporum gypseum masing-masing sebanyak 1 sampel (Tabel 3).

\section{PEMBAHASAN}

Pada penelitian ini menunjukkan bahwa dermatofitosis lebih banyak diderita oleh laki-laki dibandingkan perempuan. Hal ini mungkin disebabkan karena laki-laki memiliki aktifitas yang lebih banyak dan berat sehingga lebih mudah berkeringat sehingga peluang untuk menderita dermatofit lebih besar dibandingkan perempuan. Hal ini sejalan dengan yang dikatakan oleh Verma \& Heffernan (2008), bahwa laki-laki $3 x$ lebih sering menderita dermatofit dibandingkan perempuan, tapi hal tersebut tidak dapat dijadikan gambaran untuk keseluruhan populasi. Hal ini dapat disebabkan tidak seimbangnya komposisi jenis kelamin sampel.

Dari 50 sampel dapat dilihat distribusi penderita dermatofit lebih banyak diderita pada usia produktif yaitu 17-45 tahun. Data ini sesuai dengan penelitian yang dilakukan oleh Riani (2008), dimana usia produktif lebih beresiko menderita dermatofitosis dibandingkan usia anak-anak dan usia tua. Hal ini mungkin disebabkan karena usia produktif mempunyai faktor predisposisi, misalnya mereka bekerja di pekerjaan basah, trauma, dan banyak berkeringat, sehingga resiko untuk menderita dermatofit lebih besar dibandingkan dengan kelompok umur lainnya. Hal ini juga sejalan dengan penelitian yang dilakukan oleh Wahdini et al (2015) dimana kelompok usia produktif sangat rentan menderita dermatofitosis karena memiliki aktivitas yang paling tinggi sehingga banyak berkeringat.

Dari 50 sampel kerokan kulit yang kami peroleh dari Balai Kesehatan Kulit, Kelamin dan Kosmetik, kartini medical center dan Beberapa Sekolah Dasar yang berada di 
Kota Makassar yang selanjutnya di amplifikasi dengan menggunakan metode Multipleks PCR didapatkan hasil terbanyak adalah Microsporum spp. (54\%) kemudian dermatofit (diluar 11 spesies) sebanyak $20 \%$. Metode Multipleks PCR ini mampu mendeteksi 11 spesies dermatofit yaitu Epidermophyton floccosum, Microsporum canis, Microsporum audoinii, Trichophyton violeceum, Trichophyton rubrum, Trichophyton mentagophytes var. mentagrophyte, Trichophyton tonsurans, Trichophyton mentagrophyte var. interdigitale, Trichophyton verrocosum, Microsporum gypseum, dan Microsporum fulvum (Kim et al., 2011). Sedangkan spesies dermatofit lainnya diantaranya T.megninii, T.concentricum, M.ferrugineum, T. schoenleinii dapat diamplifikasi dengan ukuran pita yang tidak khas untuk spesies tersebut (Kurniati \& Rosita, 2008), Keunggulan multiplex PCR bila dibandingkan dengan metode PCR lainnya, yaitu adanya kontrol internal dari amplifikasi beberapa fragmen sekaligus. Hal ini berfungsi untuk mengetahui adanya hasil negatif palsu. Reaksi dapat dikatakan negatif atau gagal apabila seluruh produk tidak tampak pada visualisasi. Bila hanya satu atau beberapa produk saja dari seluruh fragmen yang diamplifikasi tidak tampak, dapat dikatakan hasil adalah negatif palsu, Multiplex PCR lebih mampu mengindikasikan kualitas template DNA dibandingkan pada PCR tunggal. Penurunan kualitas template DNA akan menunjukkan pita-pita panjang lebih lemah dibandingkan yang pendek, Efisiensi biaya dan waktu persiapan bila dibandingkan dengan multiplex tunggal, Multiplex PCR merupakan teknik yang dapat dipilih bila ingin mengeluarkan biaya serta menggunakan sampel yang relatif sedikit.

\section{KESIMPULAN}

Dengan metode Multipleks PCR didapatkan hasil terbanyak yaitu Microsporum spp. (54\%) pada sampel kerokan kulit pasien dermatofitosis $(\mathrm{KOH}+)$.

\section{SARAN}

Berdasarkan penelitian ini kami menyarankan diperlukan penelitian lebih lanjut pada populasi yang berbeda yaitu selain Kota Makassar, diperlukan penelitian lebih lanjut terhadap Multipleks PCR dengan menggunakan primer yang berbeda dan Pihak laboratorium dapat menggunakan amplifikasi PCR untuk konfirmasi jenis dermatofit karena hasilnya dapat lebih cepat dan spesifik.

\section{UCAPAN TERIMA KASIH}

Ucapan terima kasih kami ucapkan kepada pihak Balai Kesehatan Kulit, Kelamin dan Kosmetik, Kartini medical center serta Beberapa Sekolah Dasar yang berada di Kota Makassar yang telah mengizinkan kami untuk mengambil sampel di instansi mereka serta pihak laboratorium Mikrobiologi Rumah Sakit Pendidikan UNHAS yang telah membantu kami dalam melakukan penelitian ini.

\section{DAFTAR PUSTAKA}

Adiguna MS. 2011. Update Treatment In Inguinal Intertrigo And Its Differential Diagnosis. Bagian/SMF IImu Kesehatan Kulit dan Kelamin Fakultas Kedokteran Universitas Udayana. 309-333

Edward M. C. \& Gibbs R.A. 1994. Multiplex PCR: advantages, development, and applications. Genome Res. 3: 65-75.

Garg J. et al. 2009. Rapid Detection of Dermatophytes From Skin and Hair. BMC Res Notes. 2:60-65

Kim. et al. 2011. Identification Of Dermatophytes Using Multiplex Polymerase Chain Reaction. Departement Of Dermatology. Konkuk Univesity School Of Medicine, Seoul, Korea. 23;3

Kurniati \& Rosita C. 2008. Etiopatogenesis Dermatofitosis. Berkala IImu Kesehatan Kulit Dan Kelamin FK UNAIR. Surabaya, 20, 243-50

Lee YW. 2010. Molecular analysis for identification and classification of dermatophytes. Korean J Dermatol. 48:82.

Paramata N.R. \& Massi N. 2009. The Comparasion Of Sensitivity Test Of Itraconazole Agent The Causes Of Dermatophytosis In Glabrous Skin In Makassar. Makassar: Bagian Mikrobiologi Fakultas Kedokteran Universitas Hasanuddin

Riani E. 2008. Hubungan Antara Karakteristik Demografi, Gaya Hidup dan Perilaku Pasien Puskesmas di Jakarta Selatan Dengan Dermatofitosis. Vol.2:2

Sondakh, Cyndhi. et al. 2016. Profil Dermatofitosis di Poliklinik Kulit dan Kelamin RSUP Prof. Dr. R.D. 
Kandou Manado priode JanuariDesember 2013. Jurnal e-Clinic (eCl), Volume 4 nomor 1

Sopiyudin D.H. 2013. Besar Sampel dan Cara Pengambilan Sampel. Jakarta:Salemba Medika

Verma S. \& Heffernan M.P. 2008. Superfisial Fungal Infection: Dermatophytosis, Onychomycosis, Tinea Nigra, Piedra. Dalam: Wolff, K. (eds). Fitzpatrick's Dermatology in General Medicine. Vol.II. Ed.7. United States: Mcgraw-Hill, 1807-1821

Wahdini, M. et al. 2015. Karakteristik Pasien dan Spesies Dermatofita Penyebab Tinea Kruris di Rumah Sakit Umum Daerah Gunung Jati Cirebon Jawa Barat. Global Medical and Health Communication. Vol 3;2. 
Tabel 1. Data Demografi berdasarkan Jenis Kelamin

\begin{tabular}{lcc}
\hline \multicolumn{1}{c}{ Jenis Kelamin } & Jumlah & $\%$ \\
\hline Laki-laki & 27 & $54 \%$ \\
Perempuan & 23 & $46 \%$ \\
Total & 50 & $100 \%$ \\
\hline
\end{tabular}

Tabel 2. Data Demografi berdasarkan Umur

\begin{tabular}{|c|c|c|}
\hline Umur & Jumlah & $\%$ \\
\hline$<17$ tahun & 23 & $46 \%$ \\
\hline 17-45 tahun & 24 & $38 \%$ \\
\hline$>40$ tahun & 2 & $16 \%$ \\
\hline Total & $50 \%$ & $100 \%$ \\
\hline
\end{tabular}

Tabel 3. Hasil PCR dengan menggunakan metode Multipleks PCR

\begin{tabular}{|c|c|c|}
\hline Spesies & Jumlah & $\%$ \\
\hline Microsporum spp. & 27 & $54 \%$ \\
\hline Microsporum audoinii & 4 & $8 \%$ \\
\hline Microsporum vulvum & 3 & $6 \%$ \\
\hline Microsporum gypseum & 1 & $2 \%$ \\
\hline $\begin{array}{l}\text { Trichophyton mentagrophytes var. } \\
\text { interdigitale }\end{array}$ & 4 & $8 \%$ \\
\hline Trichophyton tonsurans & 1 & $2 \%$ \\
\hline $\begin{array}{l}\text { Dermatofit spesies lain (diluar } 11 \\
\text { spesies) }\end{array}$ & 10 & $20 \%$ \\
\hline Total & 50 & 100 \\
\hline
\end{tabular}




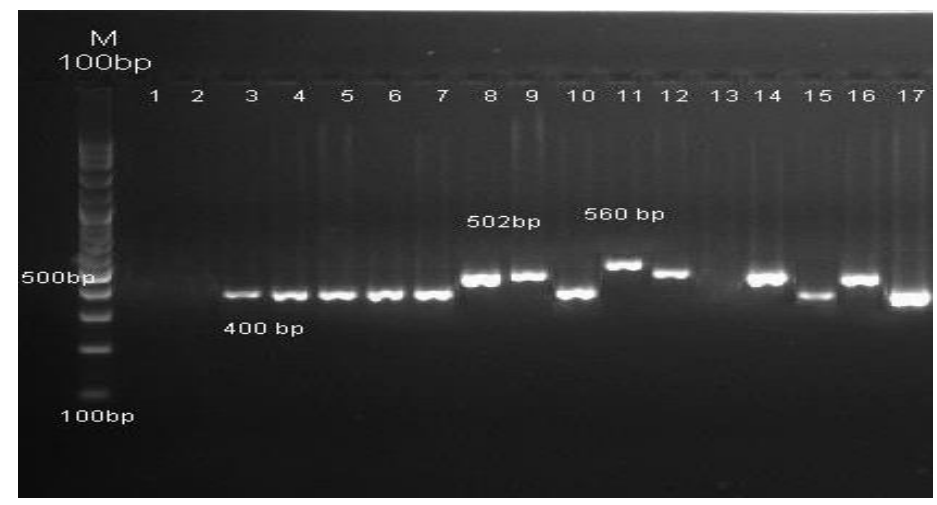

a. Primer ITS 1-2

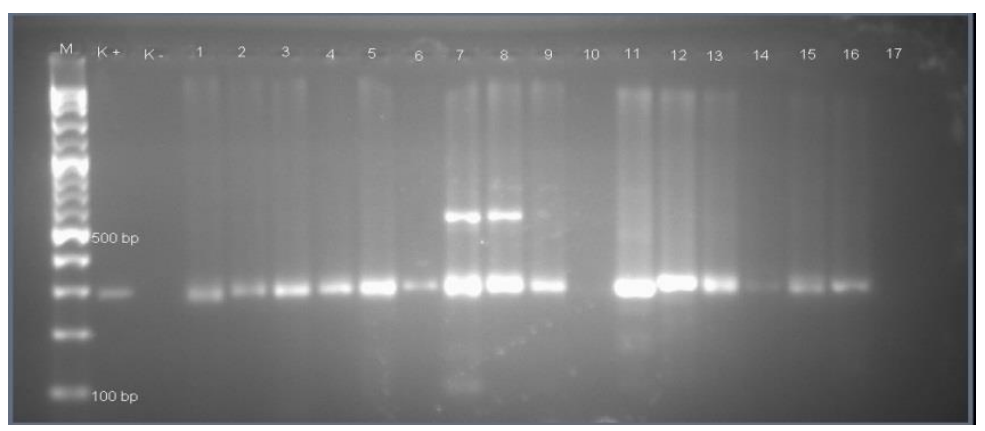

b. Primer $28 \mathrm{~s}$

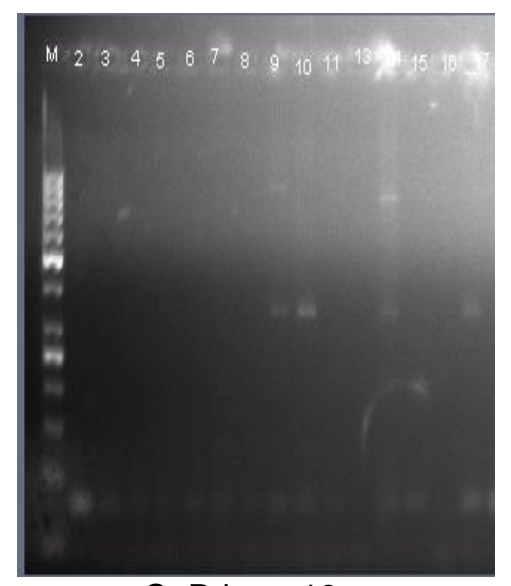

C. Primer $18 \mathrm{~s}$

Gambar 1. a. Primer ITS1-2, b. Primer 28s RNA, c. Primer 18s RNA, M=marker 